"I am sorry to say that the "fish booming and drumming,' described by Charles Kingsley, was not to be heard. Either we were there at the wrong season, or the fish had been driven away by the use of dynamite. From all I heard, the sound was identical with that produced by the drum-fish so common in the Indian river of Hinda."

\section{ROBERT MALLET, F.R.S.}

$T$ HIS eminent engineer, whose researches on earth quakes are so well known to scientific men, died on the 5 th inst. at the age of seventy-one. During his very active career he accomplished a vast amount of work, of which his "Earthquake Catalogue" and other published books and memoirs form the best monument.

Robert Mallet was born in Dublin on June 3, $18 \mathrm{ro}$. $\mathrm{He}$ was descended from the representative of a Devonshire family who had settled in Ireland, his father being the owner and manager of an engineer's factory. During childhood Robert Mallet appeared to be of weakly constitution, but he grew up to be a man with great powers of endurance. His taste for science was exhibited at a very early period, and before he had reached the age of twelve years he had established a laboratory in his father's house, where he delighted in performing chemical experiments. After being taught in a private school in Dublin, and making a tour on the Continent, he entered as a student at Trinity College, Dublin, and in I 830 completed his studies there by taking his M.A. degree. In 1831 he made an extended tour on the Continent, and, upon his return, married, and entered into partnership with his father. From this time forth he was busily engaged in various engineering projects both in the capital and in various parts of Ireland. Private study and research were, however, by no means neglected during these busy times, and in the very year of his commencing business we find him publishing his first paper on the motion of glaciers. He had before this time been elected a member of the Royal Irish Acalemy. In I 839 Mallet was elected a member of the Institute of Civil Engineers, and in the same year made his important invention of "buckled plates," an invention which was not patented till 1852 , the patent being prolonged in 1866 . It was in 1846 that Mallet published his first paper on Earthquake Phenomena; this memoir, which appeared in the Philosophical Magazine, gave a simple explanation of the supposed "vorticose movements" during earthquakes, and two years later a paper in the Transactions of the Royal Irish Academy contained a full exposition of his views on the wavemovement in earthquakes, with which every one is now familiar. During subsequent years Mallet published in the British Association Reports his papers, which aimed at drawing up a complete catalogue of earthquakes, with various contributions to seismology and seismometry. In 1857 occurred the great earthquake in the Neapolitan territory, and in the following year Mr. Mallet was commissioned by the Royal Society to proceed to the district and to study its effects.

The results of his observations were published in two volumes in 1862 . In 1858 the Earthquake Catalogue was completed by Robert Mallet with the aid of his son, now Prof. J. W. Mallet of Virginia. About this time we find Mallet engaged in experiments upon artillery, and in calling attention to a new gun which he had invented, but which never seems to have been of much practical utility. In 1872 Mallet laid before the Royal Society a memoir, to which he had evidently, during many years, devoted much ti.ne and labour; it was entitled "On Vol zanic Energy, an Attempt to Develop its True Nature and Cosmical Relations."

Waatever differences of opinion may bə entertained as to the truth of the theory which is there sought to be established, there can be none whatever as to the value of the experiments which constitute its basis, or of the important influence which it has exercised upon geolozical thought and speculation. This important memoir, which was published in the Philosophical Transactions, has been translated into German by Prof, von Lasaulx, who has added a valuable commentary to it.

During the later years of his life, Mallet, who had removed from Dublin to London, was afflicted with almost total blindness, but he nevertheless continued to make occasional contributions to his favourite branches of science. Altogether he was the author of more than seventy memoirs, besides separately published works. Mr. Mallet was elected a Fellow of the Royal Society in I854 and of the Geological Society in 1859 ; in 1877 he was awarded the Wollaston medal of the latter society.

\section{THE LAND OF THE MIDNIGHT SUN}

T NDER the above striking title we have an account of the Peninsula of Scandinavia and of the life of its people, based on a series of journeys made at different times. from I87 I to I878, by Mr. Paul Du Chaillu. It is pleasant to meet with an author, already so well known for his travels in Equatorial Africa on new ground, and to find that his journeyings on virgin soil and among wild and savage races have not unfitted him for the study of the physical characteristics of an old country, and of the manners and customs of its inhabitants. The reader of these two handsome and well-illustrated volumes may form some notion of the extent of ground traversed during a five-years' sojourn, from the tracings of the author's routes on the map appended to the first volume. Not only was the country travelled over from north to south and from east to west, but the coast-line from Haparanda to the extreme north-eastern point of Norway, a distance of 3200 miles, was observed, the greater part of it both in winter and in summer, and over 3000 miles of fjords were sailed along. The illustrations are most frequently from photographs, but those representing Lapland winter scenes are the work of a Swedish artist.

A great many pages of this work, while pleasant reading, will not afford much new information to the reader who may have already travelled in Sweden or Norway. The route from London to Göteborg, Stockholm with its beautiful suburbs, Upsala, Christiania, Bergen, the Dovrefeld, the splendid scenes of the Romsdal; these and a few more well-known routes and places are all within the compass of an ordinary summer's tour; but Du Chaillu has told of these all in an attractive and appreciative manner, and he treats of many such only by the way as he journeys on to places seldom visited even by the sportsman in pursuit of game. He gives a good deal of interesting information about the Laplanders. The Lapps are described as kind-hearted, dirty people. Their life during summer is a very hard one. They have to follow their reindeer day and night, lest the herds should wander. Coffee was their principal drink, mixed with the thick reindeer's milk. They were a fair-haired and fair-skinned people, with blue eyes, prominent cheekbones, and the nose retroussé. The men were from four feet five to five feet and one-quarter inch in height, and three women measured four feet and one-quarter, four feet and three-quarters, and four feet six and threequarters of an inch in height respectively. It was at the Lapp village of Jockmock that Prof. Baron von Duiben, so well known and appreciated in this country for his writings, was met with. He was engaged in the study of the Lapps when Du Chaillu, fatigued and hungry, found himself entering the station. Lon zing to see a human

x "The Land of the Midnight Sun: Summer and Wanter Journeys through Sweden, Norway, Lapland, and Northern Finland. With Descriptions of the Incer Life of the People, their Manners and Customs, their Primitive Antiquities, \&c." By Paul B. Du Chaillu. In two volumes, with map an!235 illustrations. (Londsn: John Murray, I88x.) 